\title{
Fluctuations in the biochemical composition of the Patagonian stone crab Platyxanthus patagonicus A. Milne Edwards, 1879 (Platyxanthidae: Brachyura) throughout its reproductive cycle
}

\author{
JIMENA B. DIMA ${ }^{1,2}$, NORMA A. DE VIDO ${ }^{2}$, GUSTAVO A. LEAL ${ }^{2}$ \\ and PEDRO J. BARÓN ${ }^{1,2}$ \\ ${ }^{1}$ National Technological University, Academic Unit Chubut (UACh-UTN), Roberts 56, (9120) Puerto Madryn, \\ Chubut, Argentina. \\ ${ }^{2}$ National Patagonian Center, National Council of Scientific and Technical Research (CENPAT-CONICET), Boulevard \\ Brown 2825, (9120) Puerto Madryn, Chubut, Argentina. E-mail: baron@ cenpat.edu.ar
}

\begin{abstract}
SUMMARY: We analyzed the gonadosomatic (GSI) and hepatosomatic (HSI) indices, reproductive condition and biochemical composition of the digestive gland, gonads and claw muscle of the Patagonian stone crab over a one-year period. In females, the maximum HSI occurred in spring (gonad recovery period) and summer (maximum maturity period). The maximum female GSI values were found in summer, and fell to minimum values in fall and winter. In males, the highest GSI was observed during winter, which coincided with a non-mating period. The claw muscle biochemical composition did not significantly differ between seasons for either sex, except for the significantly lower glycogen content observed in winter relative to fall and summer in males. For both sexes, the claw muscle contained 72.4 to $81.2 \%$ moisture, 12.3 to $19.8 \%$ protein, 0.3 to $1.0 \%$ fat, 1.1 to $2.7 \%$ ash and 0.1 to $1.4 \%$ glycogen. In both sexes, the digestive gland was the main storage site for lipids. In the ovary, lipid and protein contents were higher in spring and summer, and decreased to significantly lower values after spawning. Moisture showed the opposite pattern and neither glycogen nor ash contents showed significant differences between seasons. The biochemical composition of the testes-vasa deferentia complex did not show significant seasonal fluctuations, except for higher moisture content in fall compared to summer and spring.
\end{abstract}

Keywords: stone crab, biochemical composition, reproduction, gonadosomatic index, hepatosomatic index.

RESUMEN: Composición bioquímica de Platyxanthus patagonicus A. Milne Edwards, i879 (Platyxanthidae: BraCHYURA) Y SUS FLUCTUACIONES A LO LARGO DEL CICLO REPRODUCTIVO. - Se analizaron los índices gonadosomático (IGS) y hepatosomático (IHS), la condición reproductiva y la composición bioquímica de la glándula digestiva, gónadas y músculo de las quelas de Platyxanthus patagonicus durante un período anual. En las hembras, el máximo IHS ocurrió en primavera (período de recuperación gonadal) y verano (período de máxima madurez). El máximo IGS fue alcanzado en verano, decreciendo a mínimos valores en otoño e invierno. En los machos, el máximo IGS fue observado en invierno, coincidiendo con un período de inactividad en el apareamiento. Para ambos sexos, la composición bioquímica del músculo de las quelas no difirió significativamente entre las estaciones del año, excepto por el contenido en glucógeno, significativamente menor en invierno respecto a otoño y primavera en los machos. Para ambos sexos tomados conjuntamente, el músculo de las quelas contuvo 72.4-81.2\% de humedad, 12.3-19.8\% de proteína, 0.3-1.0\% de lípidos, 1.1-2.7\% de ceniza y 0.1-1.4 de glucógeno. En ambos sexos la glándula digestiva fue el principal sitio de almacenamiento de lípidos. En el ovario, el contenido de lípidos fue mayor en primavera y verano, decreciendo a valores significativamente menores después del desove, el contenido de humedad mostró el patrón opuesto y los contenidos de glucógeno y cenizas no presentaron diferencias significativas entre estaciones. En el complejo testículos-vasos deferentes, la composición bioquímica no mostró fluctuaciones estacionales, excepto por un mayor contenido en humedad en otoño respecto al verano y la primavera.

Palabras clave: Platyxanthidae, composición bioquímica, reproducción, índice gonadosomático, índice hepatosomático. 


\section{INTRODUCTION}

Seafood products are currently in high demand as they are considered healthy and nutritional (Leu et al., 1981; Connor and Lin, 1982; King et al., 1990; Skonberg and Perkins, 2002). As a result, capture of marine shellfish has increased exponentially during the last century, and now exceeds 13 million $\mathrm{t}$ (FAO, 2008). Marine brachyurans (true crabs) represent one tenth of this total (1.38 million $t$ in 2006) (FAO, 2008).

In spite of their economic potential, brachyurans such as the Patagonian stone crab Platyxanthus patagonicus A. Milne-Edwards are still poorly targeted in some regions (Baltz and Horst, 1992; Chauvet and Kadiri-Jan, 1999). This species has been virtually unexploited to date despite its wide latitudinal (29 to $47^{\circ} \mathrm{S}$ along the Atlantic coast of South America) (Nakamura et al., 1986; Melo, 1990; Boschi et al., 1992) and bathymetric (0 to $155 \mathrm{~m}$ depth) (Nakamura et al., 1986) distribution and its large size (up to 146 $\mathrm{mm}$ in carapace width and almost $1 \mathrm{~kg}$ in total fresh weight). Like other members of the Xanthoidea (such as stone crabs), mature males of this species have large chelae in comparison to females, making them a suitable target for "claw exploitation" (Restrepo, 1992; Carsen et al., 1996) and for the production of specialty fresh and frozen products (Abugoch et al., 1996). However, very little is known about the species' biology (Carsen et al., 1996; Leal et al., 2008) and no information is available on its biochemical composition.

Knowledge of crustacean biochemistry and metabolic processes throughout the year not only improves the understanding of the most relevant physiological processes, namely reproduction and growth, but also facilitates processing, utilization and marketing of value-added products (Skonberg and Perkins, 2002). For this reason, biochemical changes in the gonads, digestive gland and muscle during maturation, molting and reproduction have been examined in many species of decapod crustaceans (Gehring, 1974; Read and Caulton, 1980; Du Preez and McLachlan, 1983; Galois, 1984; Wheaton and Lawson, 1985; Castille and Lawrence, 1989; Cifuentes and Quiñinao, 2000; Gökoðlu and Yerlikaya, 2003; Hasek and Felder, 2005, 2006).

The objective of the present work is to describe the seasonal fluctuations of the biochemical composition of the gonads, digestive gland and claw muscle of $P$. patagonicus, and relate them to the physiological condition of the gonads throughout the reproductive cycle. Results reported here improve the understanding of the physiology and biochemistry of this and other brachyuran species.

\section{MATERIALS AND METHODS}

Hard shelled Patagonian stone crabs were collected monthly from November 2004 to October 2005 in Nuevo Gulf (Argentina, 42 ${ }^{\circ}-43^{\circ} \mathrm{S}, 64^{\circ}$ $65^{\circ} \mathrm{W}$ ) between the 30 and $50 \mathrm{~m}$ isobaths using baited collapsible traps that were left overnight. After capture, crabs were taken alive to the lab, classified according to sex, weighed with a Mettler P3N balance to the nearest $1 \mathrm{~g}$, measured with a Digimess electronic caliper to the nearest $0.1 \mathrm{~mm}$ in carapace width (CW), and staged according to the maturity scale developed by Leal et al. (2008) for the species after careful removal of the carapace. Crabs infested by rhizocephalan parasites were excluded from the samples. Monthly sub-samples of 7 to 11 maturesized individuals from both sexes $(\mathrm{CW}>90 \mathrm{~mm}$ for males; $\mathrm{CW}>64 \mathrm{~mm}$ for females) were randomly selected from each batch. Crabs were placed upside down for 20 minutes to allow drainage of body fluids, and then the ovary, testes-vasa deferentia complex, digestive gland and claw muscle were dissected and removed from the crabs and weighted with a Mettler PC 440 Delta Range ${ }^{\circledR}$ electronic balance. The gonadosomatic (GSI) and hepatosomatic (HSI) indices were calculated from these data as:

GSI = wet weight of the ovary / whole crab wet weight (in females),

GSI = wet weight of the testes-vasa deferentia complex / whole crab wet weight (in males),

HSI = wet weight of the digestive gland / whole crab wet weight.

The biochemical composition of the gonads, digestive gland and claw muscle was analyzed separately using monthly pooled samples of males and females. Moisture content was determined by drying at $100^{\circ} \mathrm{C}$ to a constant weight (AOAC, 1980); protein content was established using the Lowry method (Lowry et al., 1951); lipid content was estimated by extraction with ethylic ether in a Soxhlet system (AOAC, 1980); glycogen content was determined by colorimetry using the Antrhone reagent according to the method described by Fraga (1956), and ash content was obtained as the difference between constant dry weight of tissues and the weight of 
the tissues after incineration in a furnace at $550^{\circ} \mathrm{C}$. Analyses were performed in duplicate. Results were expressed as the averaged percentage of each biochemical component relative to the wet weight. The energy content in the different tissues of the crabs was estimated by converting the protein, lipid and glycogen contents to their equivalents in $\mathrm{Kcal} / \mathrm{g}$, employing Rubner's coefficients (Winberg, 1971).

Condition indices (GSI and HIS) were compared between sexes with the Mann-Withney U test, and between seasons using the Kruskal-Wallis and T statistic tests for comparing pairs of treatments (Connover, 1999). The biochemical composition was compared between: 1) different seasons for each organ/tissue and sex, 2) different organs/tissues for the same season and sex, and 3) different sexes for the same organ/tissue and season, using the same statistical tests as for the condition indices. Statistica 6.0 and electronic spreadsheets were used for calculations.

\section{RESULTS}

The GSI and HSI showed significant differences between seasons, both for females and males (Fig. 1). In females, the GSI was significantly higher in summer compared to the other seasons, and was also higher in spring relative to fall and winter (Fig. 1). However, the male GSI was higher in winter than in the other seasons (Fig. 1). In females, the HSI was higher in spring and summer, compared to fall and winter, while in males fall was the only season that showed a significantly lower HIS compared to the rest of the seasons (Fig. 1).

The biochemical composition of $P$. patagonicus showed different patterns of seasonal variation depending on the organ/tissue, sex and component analyzed (Fig. 2). In female gonads: 1) lipid content was significantly higher in spring and summer than in fall and winter; 2) moisture content showed the opposite pattern; 3) protein content was significantly higher
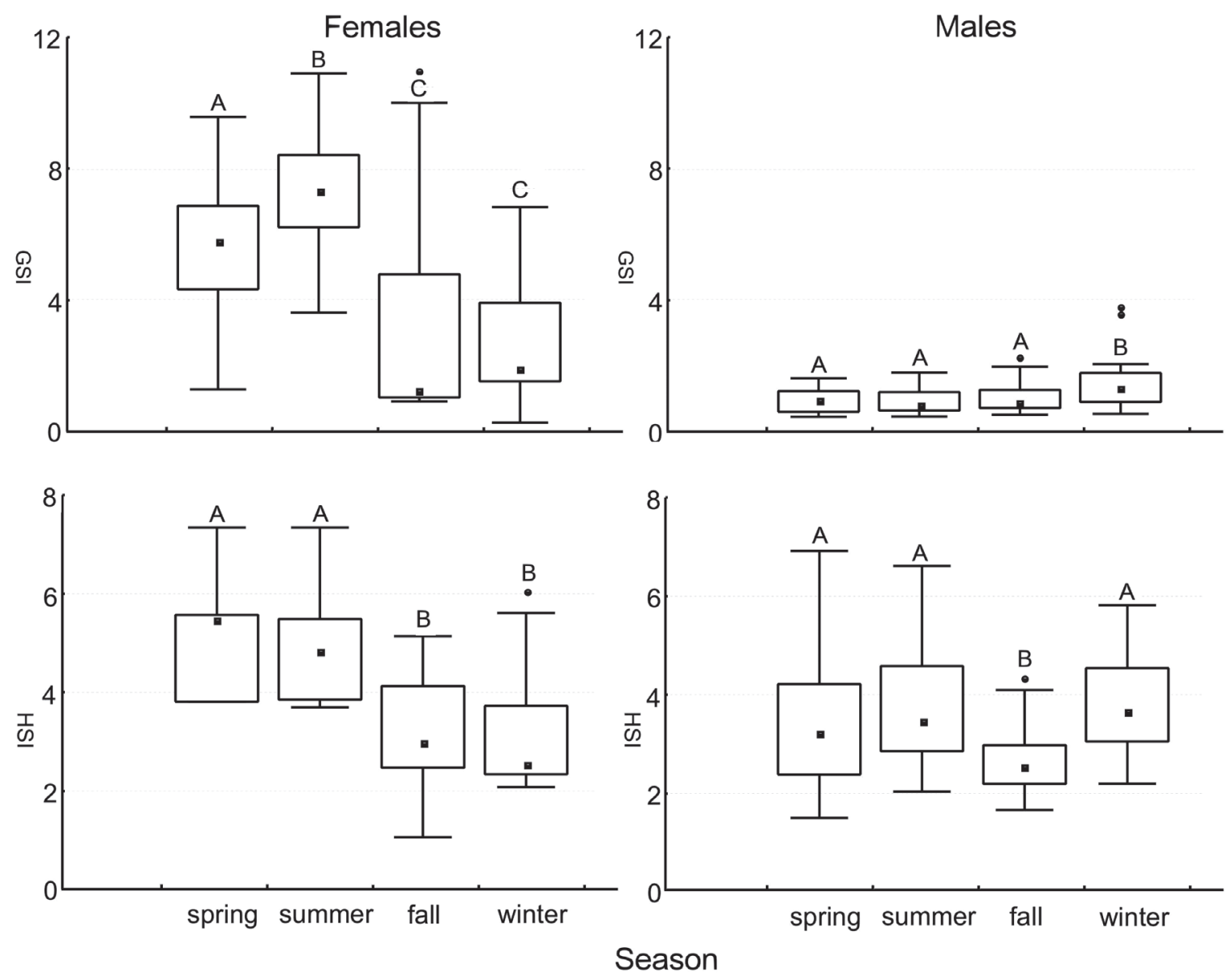

FIG. 1. - Gonadosomatic (GSI) and hepatosomatic (HSI) indices of female and male Platyxanthus patagonicus. Squared marks: median; box: inter-quartile range; bars: non-outlier range; circles: outliers. Different/equal capital letters on top of the box plots represent significant/nonsignificant differences between seasons (Kruskal Wallis tests, $\mathrm{P}<0.05$ and $\mathrm{T}$ statistic tests comparisons between pairs of treatments, $\mathrm{P}<0.05$ ). 

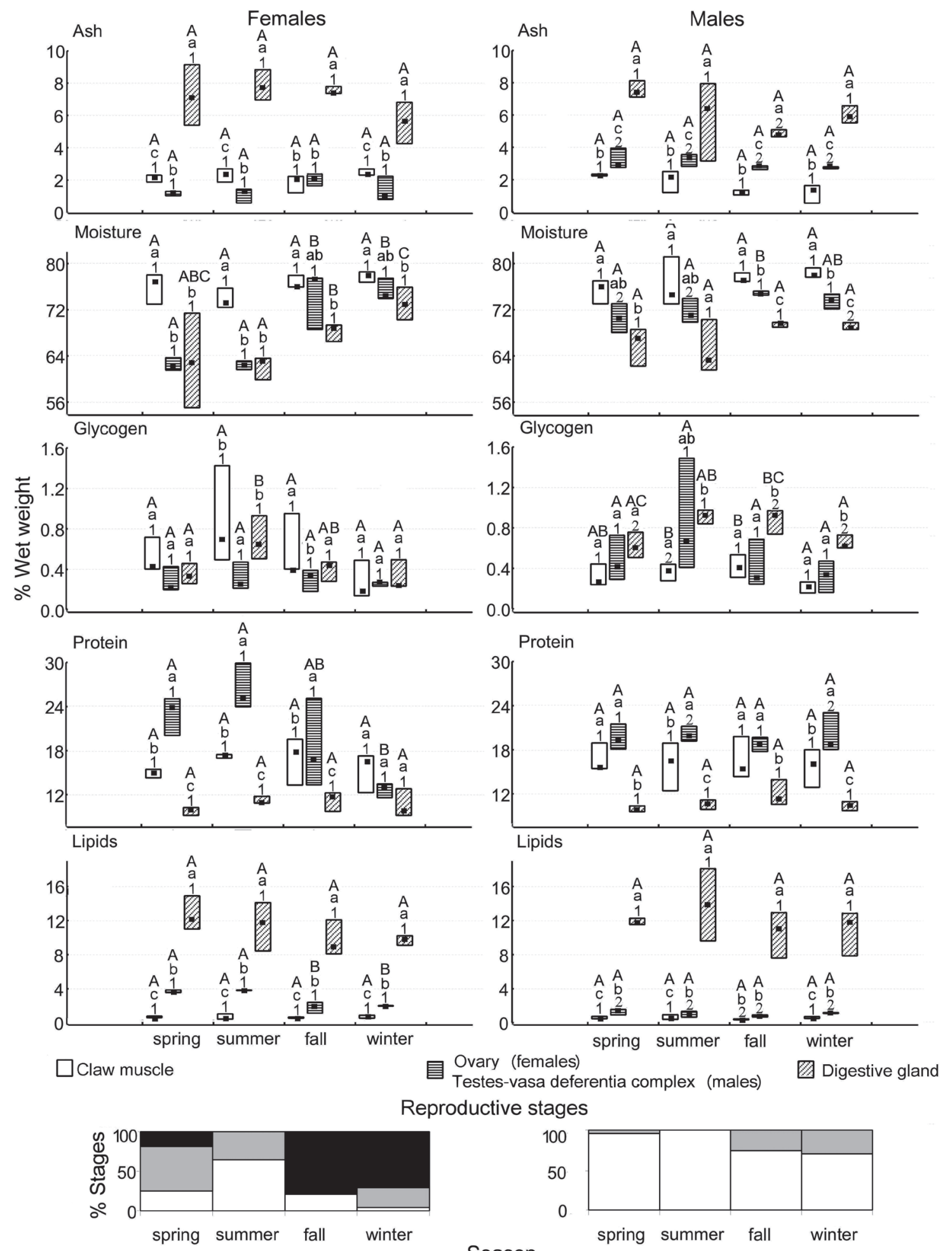

Mature gonads

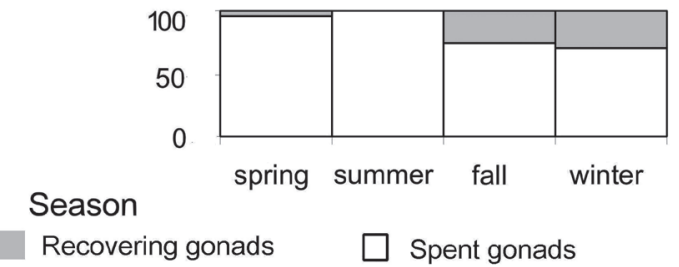

FIG. 2. - Biochemical composition (box plots) and percentage of different stages of gonadal maturity (stacked bar plots) of female (left) and male (right) Platyxanthus patagonicus in different seasons of the year. Squared marks: median; box: range. Different/equal capital letters on top of the box plots represent significant/non-significant differences (Kruskal Wallis test, $\mathrm{P}<0.10$ and $\mathrm{T}$ statistic test comparisons between pairs of treatments, $\mathrm{P}<0.05$ ) between seasons for each combination of organ/tissue and sex; different/equal lower-case letters represent significant/non-significant differences (Kruskal Wallis test, $\mathrm{P}<0.10$ and $\mathrm{T}$ statistic test comparisons between pairs of treatments, $\mathrm{P}<0.05$ ) between organs/tissues for each combination of season and sex; Different/equal numbers represent significant/non-significant differences (Mann and Whithney $\mathrm{U}$ test, $\mathrm{P}<0.05$ ) between sexes for each combination of organ/tissue and season. 
in spring and summer than in winter; and 4) ash and glycogen contents did not show significant seasonal variations (Fig. 2). The seasonal mean lipid content showed a high positive correlation with that of protein $(\mathrm{R}=0.80)$. In the female digestive gland: 1$)$ the lipid content did not show significant seasonal differences; 2) the moisture content showed significant differences between all seasons except for spring, in which the largest variability was observed; and 3) glycogen was only significantly higher in summer (Fig. 2). The biochemical composition of female claw muscles did not show significant seasonal differences (Fig. 2). The most interesting findings of the comparison between the biochemical composition of female organs/tissues were that: 1) lipid and ash contents in the digestive gland were significantly higher than in the ovary and claw muscles in all seasons, and 2) glycogen content did not show significant seasonal differences between organs/tissues, except for the higher values observed in the digestive gland and claw muscle in relation to the gonads during summer (Fig. 2).

In male $P$. patagonicus: 1$)$ the testes-vasa deferentia complex showed no significant seasonal differences in biochemical composition, except for the higher moisture contents observed in fall compared to summer and spring; 2) the digestive gland displayed no significant seasonal differences in biochemical composition, except for the lower glycogen content in spring relative to summer, and in winter relative to fall; and 3) male claw muscles showed no significant seasonal differences in biochemical composition, except for the lower glycogen content in winter relative to fall and summer (Fig. 2). The most prominent results of the comparison between the biochemical composition of male organs/tissues were that: 1) the protein content in testes-vasa deferentia complex was significantly higher than that of the claw muscle in winter and summer, and the protein content of the digestive gland was lower than that of the other organs/tissues in all seasons; 2) the lipid content in the digestive gland was higher than that of the other organs/tissues in all seasons, the glycogen content was significantly higher in fall and winter, and moisture content was significantly lower in fall and winter; and 3) overall, moisture content in male claw muscles was higher than in the other organs/tissues, but no significant differences were observed in relation to the gonads in spring and summer, ash content was significantly lower than that in the other organs/tissues in all seasons, and lipid content was also significantly lower, except for the summer (Fig. 2).

The comparison of the ovary and the testes-vasa deferentia complex showed that: 1) the lipid content in the ovary was significantly higher in all seasons; 2) ash content displayed the opposite pattern; 3) glycogen content did not show significant differences; and 4) protein and moisture contents showed significant differences only in some of the seasons (Fig. 2 ). The comparison of the digestive gland from both sexes revealed that: 1) the lipid and protein contents

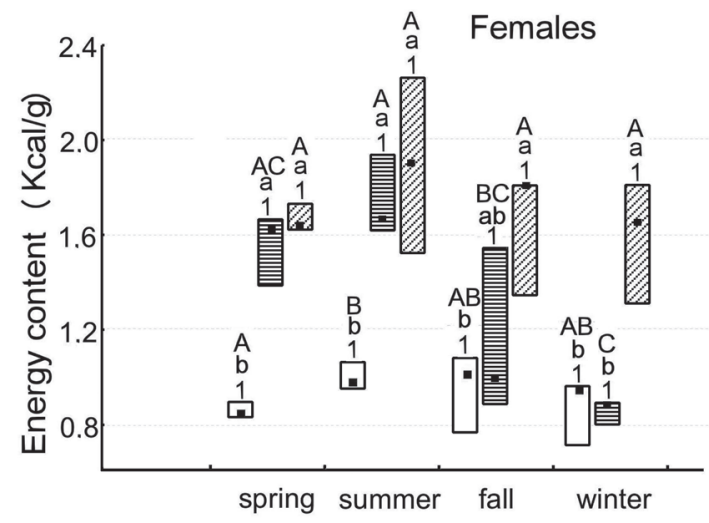

Claw muscle

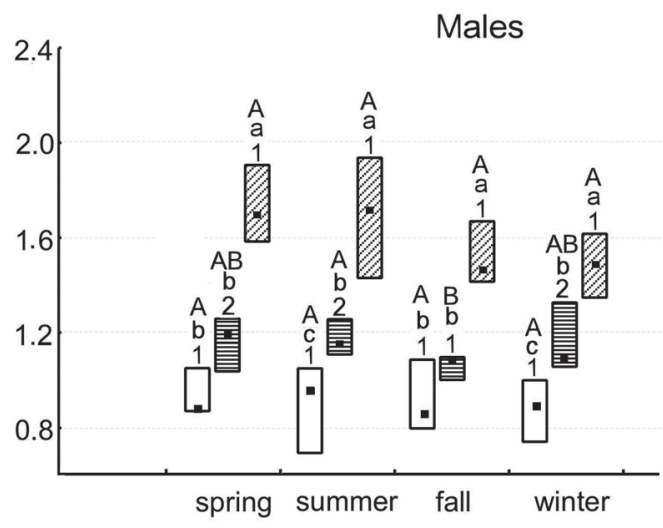

Season

Ovary (females)

Testes-vasa deferentia complex (males)
Digestive gland

FIG. 3. - Seasonal energy content in different organ/tissues of female (left) and male (right) Platyxanthus patagonicus. Squared marks: median; box: range. Different/equal capital letters on top of the box plots represent significant/non-significant differences (Kruskal Wallis test, $\mathrm{P}<0.10$ and $\mathrm{T}$ statistic test comparisons between pairs of treatments, $\mathrm{P}<0.05)$ between seasons for each combination of organ/tissue and sex; different/equal lower-case letters represent significant/non-significant differences (Kruskal Wallis test, $\mathrm{P}<0.10$ and $\mathrm{T}$ statistic test comparisons between pairs of treatments, $\mathrm{P}<0.05$ ) between organs/tissues for each combination of season and sex; Different/equal numbers represent significant/non-significant differences (Mann and Whithney U test, $\mathrm{P}<0.05$ ) between sexes for each combination of organ/tissue and season. 
did not show significant differences in any season; 2 ) the glycogen content was significantly higher in males in all seasons except summer; and 3) the ash and moisture contents were significantly higher in males in fall and winter respectively (Fig. 2). The biochemical composition of the claw muscle showed no significant differences between males and females, except for higher levels of ash, and lipid and glycogen contents in females in winter, fall and summer respectively (Fig. 2).

The energy content of the ovary was significantly higher in spring compared to winter, and in summer relative to both fall and winter, while in the testesvasa deferentia complex it was only higher in summer relative to fall (Fig. 3). No significant differences in the energy content of the digestive gland were found between sexes or between seasons in either sex (Fig. 3). In addition, no significant seasonal differences in claw muscle energy content were found in either sex, except for a higher content in summer compared to fall in females. Claw muscle energy content did not show significant differences between sexes in any season (Fig. 3).

\section{DISCUSSION}

Fluctuations in the GSI and HSI in female $P$. patagonicus reflect the physiological changes associated with the reproductive cycle: 1) both indices had high values in samples dominated by females with recovering and mature ovaries (spring - summer); 2) the decrease in their values from summer to fall matched the spawning period; and 3) their high values in spring compared to winter coincided with the rising proportion of females with recovering and mature ovaries from winter to spring. Although the joint seasonal fluctuation of GSI and HIS did not reflect a phase-lag between the two indices during ovary maturation, like that found in other crustaceans (Kyomo, 1988; Castille and Lawrence, 1989; Haefner and Spaargaren, 1993; Chu, 1999), the seasonal resolution of our analysis may not have been adequate to detect this pattern. GSI has been used to detect both steady and seasonally fluctuating spermatogenesis and spermatic content storage in crustaceans (Sastry, 1983; Kyomo, 1988; Minagawa, 1999; Swiney and Shirley, 2001). In contrast to the female GSI, the GSI of male $P$. patagonicus showed little seasonal fluctuation, with significantly higher values only in winter, which matched a non- active period (Leal et al., 2008). This contrasting behavior of the GSI is relevant for understanding, at least in part, the seasonal patterns of the biochemical composition of both sexes.

The most noticeable changes in moisture, lipid and protein contents occurred between summer and fall, which matches the spawning period (Fig. 2). The most prominent patterns associated with the reproductive cycle of female $P$. patagonicus are the high lipid and protein content and low moisture content during the periods of gonad recovery and maximum maturity (spring-summer), and the low protein and lipid content and high moisture content during the seasons with the highest frequency of spent ovaries (fall and winter). However, the higher lipid content found in the digestive gland in spring in comparison to winter may reflect an active accumulation of this compound in spring in response to the accelerated metabolism and feeding due to rising seawater temperatures during this season; the lipids may be transferred to the ovary during vitellogenesis, as reported by Heath and Barnes (1970) and Spaargaren and Haefner (1994) for other crustaceans.

It was more difficult to establish a relationship between the reproductive cycle and biochemical composition in males than in females, as all adult male $P$. patagonicus sampled in this study were either mature or in the gonad recovery stage in all seasons. High protein content in comparison to the other organs/tissues suggests that this component plays an important role in male gamete formation. Jeyalectumie and Subramoniam (1991) obtained a similar result for the portunid crab Scylla serrata de Haan.

In this study, the lipid content of the digestive gland in both sexes was significantly higher than in any other organs/tissues analyzed (7.6 to $18.1 \%$ and 8.1 to $14.9 \%$ of the wet weight for males and females respectively). Lipids accounted for no more than 1 and $4 \%$ of the wet weight of the claw muscle and testes-vasa deferentia complex respectively, which suggests that the digestive gland may act as a reservoir for lipids. A similar pattern was reported by Heath and Barnes (1970) for the European green crab (C. maenas) and by Gökoðlu and Yerlikaya (2003) for the blue crab (Callinectes sapidus Rathbun). Ash content was particularly high in the digestive gland of $P$. patagonicus (up to 9.1 and $8.1 \%$ of the wet weight in females and males respectively), especially if compared with that reported for other species (Küçükgülmez et al., 2006). 
TABLE 1. - Percentage of moisture, protein and lipids in muscle relative to the wet weight in some brachyuran species as reported by several authors.

\begin{tabular}{|c|c|c|c|c|}
\hline Species & Moisture (\%) & Protein $(\%)$ & Lipids (\%) & Reference \\
\hline Callinectes sapidus & $77.4-86.7$ & $11.9-19.2$ & $04-1.5$ & Wheaton and Lawson (1985) \\
\hline Cancer magister & $78.5-82.3$ & $14.3-23.4$ & $0.7-2.2$ & Wheaton and Lawson (1985) \\
\hline Homalaspis plana ${ }^{a}$ & 79.34 & 16.75 & 0.11 & Abugoch et al. (1996) \\
\hline Chaceon chilensis ${ }^{a}$ & 79.68 & 16.25 & 0.40 & Cifuentes and Quiñinao (2000) \\
\hline Portunus pelagicus & $75.28-80.9$ & $21.54-26.4$ & $0.61-1.21$ & Gökoðlu and Yerlikaya (2003) \\
\hline Callinectes sapidus ${ }^{a}$ & 78.02 & 19.55 & 0.44 & Küçükgülmez et al. (2006) \\
\hline Platyxanthus patagonicus (f) & $72.44-78.55$ & $12.3-19.53$ & $0.42-1.02$ & Present Study \\
\hline Platyxanthus patagonicus $(\mathrm{m})$ & $73.03-81.18$ & $12.42-19.78$ & $0.34-0.92$ & Present Study \\
\hline
\end{tabular}

In species marked with a values correspond to the mean. In the other species, values correspond to the range. The values reported for $P$. patagonicus correspond to the claw muscle and are differentiated for females (f) and males (m).

The biochemical composition of the claw muscle of $P$. patagonicus is comparable to that of several other brachyurans (Table 1). Based on our results, this species can be characterized as having low-fat meat, high protein content and stable energy content throughout the year, both in males and females. In this work the relationships that stand out most are those between the biochemical composition and reproductive condition. However, other physiological processes like molting and feeding may also affect the biochemical composition. Therefore, these should be analyzed in the future to improve the current understanding of the dynamics of the physiological trade-offs in the Patagonian stone crab.

\section{ACKNOWLEDGEMENTS}

We would like to express our gratitude to the Nautical Department of the National Patagonian Center (CENPAT) for the staff's commitment during sampling activities, and to Aurora Nieto for her technical assistance in laboratory analyses. The Chemistry Service of CENPAT and the general laboratory of the National University of Patagonia at Puerto Madryn provided access to part of the analytic equipment used during this study. Our special thanks are also due to ALUAR S.A. for providing analytical compounds. The present study was funded by the BID OC-AR 1728 PICT 14700 project of the Argentinean National Agency of Scientific and Technologic Promotion (ANPCYT). Jimena Bernadette Dima was partially supported with a research grant from the National Technological University (UTN) (2005-2007) and a research grant from the Argentine Council of Scientific and Technical Research (CONICET) (2008).

\section{REFERENCES}

Abugoch, L., J. Barrios and A. Guarda. - 1996. Composición química proximal y propiedades funcionales de la carne fresca de las pinzas del cangrejo Homalaspis plana. Arch. Lat. Nut., 46: 309-314.

AOAC. - 1980. Official methods of analyses of the association of analytical chemists (15th ed.). Association of Official Analytical Chemists, Washington DC.

Baltz, D.M. and J.W. Horst. - 1992. Depth and substrate selection, sex ratio, and size distribution in an unexploited stone crab (Menippe adina) population in Barataria Bay, Louisiana. In: T.M. Bert (ed.), Proc. symp. stone crab (genus Menippe) Biol. Fish., vol. 50. Marine Research Publication, Florida Department of Natural Resources: 74-81.

Boschi, E.E., M.I. Iorio and K. Fischbach. - 1992. Catálogo ilustrado de los crustáceos estomatópodos y decápodos marinos de Argentina. Frente Marít., 10: 7-94

Carsen, A.E., S. Kleinman and M. Scelzo. - 1996. Fecundity and relative growth of the crab Platyxanthus patagonicus (Brachyura: Platyxanthidae) in Patagonia, Argentina. J. Crust. Biol., 16: 748-753.

Castille, F.L. and A.L. Lawrence. - 1989. Relationship between maturation and biochemical composition of the gonads and digestive glands of the shrimps Penaeus aztecus Ives and Penaeus setiferus (L.). J. Crust. Biol., 9: 202-211.

Chauvet, C. and T. Kadiri-Jan. - 1999. Assessment of an unexploited population of coconut crabs, Birgus latro (Linne, 1767) on Taiaro Atoll (Tuamotu Archipelago, French Polynesia). Coral Reefs, 18: 297-299.

Chu, K.H. - 1999. Morphometric analysis and reproductive biology of the crab Charybdis affinis (Decapoda, Brachyura, Portunidae) from the Zhujiang Estuary, China. Crustac. Int. J. Crust. Res., 72: 647-658.

Cifuentes, A. and J. Quiñinao. - 2000. Composición y vida útil como producto cocido del cangrejo dorado (Chaceon chilensis) proveniente del archipiélago de Juan Fernández, Chile. Invest. Mar., 28: 195-202.

Connor, W.E. and D.S. Lin. - 1982. The effect of shellfish in the diet upon the plasma lipid levels in humans. Metabolism, 10: 1046-1051.

Connover, W.J. - 1999. Practical Nonparametric Statistics. John Wiley and Sons, Inc. New York.

Du Preez, H.H. and A. Mc Lachlan. - 1983. Seasonal changes in biochemical composition and energy content of the three-spot swimming crab Ovalipes punctatus (De Haan) (Crustacea: Brachyura). J. Exp. Mar. Biol. Ecol., 72: 189-198.

FAO. - 2008. Fishstat plus. Universal software for fisheries statistics time series. V 2.3. Capture production database 1950-2006.

Fraga, F. - 1956. Determinación de glucógeno en moluscos con el reactivo de Antrona. Invest. Pesq., 3: 69-74.

Galois, R.G. - 1984. Variations in tissue lipid composition during vitellogenesis in the prawn Penaeus indicus Milne Edwards. $J$. Exp. Mar. Biol. Ecol., 84: 155-166.

Gehring, W.R. - 1974. Maturational changes in the ovarian lipid spectrum of the pink shrimp Penaeus duorarum Burkenroad. 
Comp. Biochem. Physiol. A, 49: 511-524.

Gökoðlu, N. and P. Yerlikaya. - 2003. Determination of proximate composition and mineral contents of blue crab (Callinectes sapidus) and swim crab (Portunus pelagicus) caught off the Gulf of Antalya. Food Chem., 80: 495-498.

Haefner, P.A. and D.H. Spaargaren. - 1993. Interactions of ovary and hepatopancreas during the reproductive cycle of Crangon crangon (L.). I. Weight and volume relationships. J. Crust. Biol., 13: 523-531.

Hasek, B.E. and D.L. Felder. - 2005. Biochemical composition of ovary, embryo, and hepatopancreas in the grapsoid crabs Armases cinereum and Sesarma nr. reticulatum (Crustacea, Decapoda). Comp. Biochem. Physiol. B, 140: 455-463.

Hasek, B.E. and D.L. Felder. - 2006. Biochemical contents of the ovary and hepatopancreas of Uca longisignalis and Uca nr. minax. Sci. Mar., 70: 505-517.

Heath, J.R. and H. Barnes. - 1970. Some changes in biochemical composition with season and during the moulting cycle of the common shore crab, Carcinus maenas (L.). J. Exp. Mar. Biol. Ecol., 5: 199-233.

Jeyalectumie, C. and T. Subramoniam. - 1991. Biochemistry of seminal secretions of the crab Scylla serrata with reference to sperm metabolism and storage in the female. Mol. Reprod. Dev. 30: 44-55.

King, I., M.T. Childs, C. Dorsett, J.G. Ostrander and E.R. Monsen. - 1990. Shellfish: proximate composition, minerals, fatty acid, and sterols. J. Am. Diet. Ass., 90: 677-685.

Küçükgülmez, A., M. Çelik, Y. Yanar, B. Ersoy and M. Çikrikçi. -2006. Proximate composition and mineral contents of the blue crab (Callinectes sapidus) breast meat, claw meat and hepatopancreas. Int. J. Food Sci. Technol., 41: 1023-1026.

Kyomo, J. - 1988. Analysis of the relationship between gonads and hepatopancreas in males and females of the crab Sesarma intermedia, with reference to resource use and reproduction. Mar. Biol., 97: 87-93.

Leal, G.A., J.B. Dima, F.G. Dellatorre, and P.J. Barón - 2008. Schedule of reproductive events and maturity at size of the Patagonian stone crab Platyxanthus patagonicus (Brachyura, Platyxanthidae). J. Crust. Biol., 28: 262-269.

Leu, S., S.N. Jhaveri, P.A. Karakoltsidis and S.M. Constantinides. - 1981. Atlantic mackerel (Scomber scombrus L.): seasonal variation in proximate composition and distribution of chemical nutrients. J. Food Sci., 46: 1635-1638.
Lowry, O.H., N. J. Rosebrough, A.L. Farr and R.J. Randall. - 1951. Protein measurement with the Folin-Phenol reagents. J. Biol. Chem., 193: 265-275.

Melo, G.A.S. - 1990. A presença, na litoral sudeste brasileiro, de espécies de Brachyura (Crustacea: Decapoda) originárias das regiões biogeográficas Magelãnica e Argentina do Atlântico Sul. Atlântica, 12: 71-83.

Minagawa, M. - 1999. Quantitative analysis of the seasonality of male reproduction in the spiny lobster Panulirus japonicus (Decapoda: Palinuridae). J. Crust. Biol., 19: 276-282.

Nakamura, I., T. Inada, M. Takeda and H. Hatanaka. - 1986. Important fishes trawled off Patagonia. Japan Marine Fishery Resource Research Center, Tokyo.

Read, G.H.L. and M.S. Caulton. - 1980. Changes in mass and chemical composition during the moult cycle and ovarian development in immature and mature Penaeus indicus Milne Edwards. Comp. Biochem. Physiol. A, 66: 431-437.

Restrepo, V.R. - 1992. A mortality model for a population in which harvested individuals do not necessarily die: The stone crab. Fish. Bull., 90: 412-416.

Sastry, A.N. - 1983. Ecological aspects of reproduction. In: F.J. Vernberg and W.B. Vernberg (eds.), The biology of crustacean: environmental adaptations, pp. 179-270. Academic Press Inc., New York.

Skonberg, D.I. and B.L. Perkins. - 2002. Nutrient composition of green crab (Carcinus maenas) leg meat and claw meat. Food Chem., 77: 401-404.

Spaargaren, D.H. and P.A. Haefner. - 1994. Interactions of ovary and hepatopancreas during the reproductive cycle of Cangron cangron (L.), II: Biochemical relationships. J. Crust. Biol., 14: 6-19.

Swiney, K.M. and T.C. Shirley. - 2001. Gonad development of southeastern Alaskan Dungeness crab, Cancer magister, under laboratory conditions. J. Crust. Biol., 21: 897-904.

Wheaton, F. and T. Lawson. - 1985. Processing Aquatic Food Products. John Wiley and Sons, New York.

Winberg, G.G. - 1971. Methods for the estimation of production of aquatic animals. Academic Press, London.

Scient. ed.: C. Zeng.

Received September 14, 2007. Accepted October 15. 2008.

Published online March 23, 2009. 